\title{
En tvillinggravid kvinne med polyuri og polydipsi
}

\author{
En kvinne gravid med tvillinger ble fulgt pga. økende vekstavvik hos \\ den ene tvillingen. Pasienten utviklet etter hvert polyuri og polydipsi. \\ Blodprøver ved innleggelse ga mistanke om alvorlig sykdom og hun \\ ble forløst med akutt keisersnitt.
}

\begin{abstract}
En annengangsgravid kvinne i slutten av 20årene kom til rutinemessig screening isvangerskapsuke 19. Hun var frisk og hadde før graviditeten en kroppsmasseindeks (BMI) på 18,5. Det ble påvist monokoriale/diamnionale tvillinger (felles morkake/hver sin fostersekk) og tvilling 2 ble målt noe mindre enn tvilling 1. Det var kjent at pasienten hadde uterus didelphys (dobbelt sett uterus) portio/vaginal og hun var nå gravid $i$ venstre uterus. I det første svangerskapet var hun gravid i høyre uterus, fikk prematur vannavgang i uke 35 og fødte ukomplisert.
\end{abstract}

Uterus didelphys skyldes en medfødt defekt i utviklingen av de müllerske gangene og gir økt risiko for primær infertilitet, ektopisk graviditet, residiverende aborter og for tidlig fødsel. I en studie var det kun ett av fem svangerskap som varte til terminen (1).

Pasienten ble fulgt med regelmessige ultralydundersøkelser i henhold til retningslinjer for gravide med monokoriale tvillinger (2). I svangerskapsuke 26 fant man vekstretardasjon hos tvilling 2 på $16 \%$, mens tvilling 1 var gjennomsnittlig stor. Hun kjente daglig liv fra begge, men mindre fra tvilling 2. Hun fortalte at hun var mer tørst enn før svangerskapet, men det var hun også i første svangerskap og hun oppfattet dette som normalt.

$P$ å ultralyd i svangerskapsuke 28 ble det sett økende vekstretardasjon hos tvilling 2 på $25 \%$ og hos tvilling 1 på $5 \%$. Basert på normale funn ved blodstrømsmåling ved dopplerundersøkelse av navlesnorsarterier og fostervannsmengde innenfor referanseverdiene utelukket man tvilling-tvilling-transfusjonssyndrom (3). Transvaginal ultralyd viste en lang og lukket cervix. Fortsatt kjente hun mindre liv fra tvilling 2. Hun følte seg trett på dagtid og hun hadde et rikelig væskeinntak på over 2 l daglig. Blodtrykket var $125 / 75 \mathrm{~mm}$ $\mathrm{Hg}$ og urinstiks var negativ. $\mathrm{HbA}_{1 c}$ på $4,7 \%$ (4-6) og normal glukosebelastning utelukket svangerskapsdiabetes.

Pasienten ble nå innlagt for første gang $i$ svangerskapet. Risiko for prematur fødsel ble vurdert med tanke på hennes anamnese, anatomiske forhold og tvillingenes økende vekstavvik. Hun fikk lungemodningssprøyte og ble utskrevet etter to dager.
Kvinnen ble på nytt innlagt $i$ svangerskapsuke 32. Vekstavviket var nå på henholdsvis $-35 \%$ hos tvilling 2 og $-12 \%$ hos tvilling 1. Fortsatt ga dopplerundersøkelser fine funn hos begge tvillingene. Hun klaget nå over forkjølelsessymptomer med tett nese, dyspné ved anstrengelse og hodepine. Hun manglet matlyst, men drakk fortsatt rikelig med væske og hadde hyppig vannlating. Dette hadde gradvis utviklet seg over flere måneder, med merkbar forverring siste måned.

Hyppig vannlating pga. fysiologiske forandringer i urinveiene i svangerskapet er vanlig. Polyuri, definert som vannlatingsvolum $>31$ / dag er ikke vanlig og fordrer videre undersøkelser (4).

Videre sov hun dårlig om natten og var økende trett på dagtid. Hun var afebril, hadde ingen dysuri, ingen ødemer og var normotensiv. Initiale blodprøver viste alaninaminotransferase (ALAT) på 415 U/l (10-45). Ved gjennomgang av drikke- og diureseliste hadde hun drukket 3 l og hadde en diurese på 4 l siste 24 timer. Blodprøver tatt tidlig i graviditeten viste tidligere gjennomgått hepatitt B-infeksjon. Det ble bedt om medisinsk tilsyn og utvidede blodprøver.

Normal graviditet gir liten endring i leverfunksjonsprøver. Aminotransferaser, totalbilirubin og serum-gallesyre skal ligge innenfor normalområdet. Alkalisk fosfatase (ALP) er moderat forhøyet i 3. trimester, mens albumin ligger lavere enn hos ikke-gravide. Kolesterolnivået er høyere (5). Differensialdiagnosene ved forhøyet leverenzymer i svangerskapet inkluderer hyperemesis gravidarum, intrahepatisk kolestase i svangerskapet, preeklampsi/HELLP-syndrom og akutt fettlever i svangerskap (AFLP). Hepatitt, kolelitiasis og malignitet må også utelukkes (6).

Ultralyd abdomen viste ingen steatose, gallegangsdilatasjon eller andre tegn til leversykdom. Blodprøvene viste leveraffeksjon med ASAT 214 U/l (15-35), ammoniakk 60 $\mu \mathrm{mol} / \mathrm{l}(10-50)$, bilirubin $45 \mu \mathrm{mol} / \mathrm{l}(5-25)$, albumin $20 \mathrm{~g} / \mathrm{l}(36-48), \operatorname{INR} 1,3(\leq 1,1)$ og aktivert partiell tromboplastintid (APTT) $52 \mathrm{~s}$

\author{
Alexander Nagel Tandberg* \\ alexnageltand@gmail.com \\ Kvinneklinikken \\ Sørlandet sykehus \\ * Nåværende adresse: \\ Ortopedisk avdeling \\ Sørlandet sykehus, Kristiansand
}

Engelsk oversettelse på www.tidsskriftet.no 
RAMME 1

Kriterier for diagnosen akutt fettlever i svangerskap (Swansea-kriteriene) (7). Seks eller flere av følgende tegn må være til stede og annen forklaring på symptomene mangle

- Oppkast

- Magesmerter

- Polyuri/polydipsi

- Encefalopati

- Forhøyet bilirubin

- Hypoglykemi

- Forhøyet urinsyre

- Leukocytose

- Ascites eller «bright liver» ved ultralyd

- Forhøyet ALAT/ASAT

- Forhøyet ammoniakk

- Nyresvikt

- Koagulopati (PTT > $14 \mathrm{~s}$, APTT > $34 \mathrm{~s}$ )

- Mikrovaskulær steatose ved leverbiopsi

(30-40). C-reaktivt protein (CRP) var på 12 mg/l (0-5), leukocytter på 12,9 g/l (3,5-10), glukose på 4,6 mmol/l (4,0-6,3) og haptoglobin på 0,28 (0,30-2,0). Fibrinogen og trombocytter var normale. Kreatinin var på 88 umol/l (45-90) og glomerulær filtrasjonsrate $(G F R)>60$. Hormonprøver var normale. Biokjemi og kliniske funn pekte mot diagnosen akutt fettlever i svangerskap.

Det kliniske bildet ved akutt fettlever i svangerskap er bredt og varierer fra asymptomatisk stigning i aminotransferasene til fulminant leversvikt med gulsott, uttalt koagulopati, leverencefalopati og hypoglykemi. Vanlige symptomer er anoreksi, oppkast, magesmerter og polydipsi/polyuri. Laboratorieprøver viser ofte forhøyet transaminaser, ammoniakk, bilirubin og urinsyre. De fleste har leukocytose. Mer enn halvparten har hypoglykemi og abnormale trombocyttog kreatininverdier. Koagulasjonsforstyrrelser med forlenget APTT eller partiell tromboplastintid (PTT) er vanlig (ramme 1) (7). Abdominal ultralyd har lav sensitivitet og spesifisitet og er mest nyttig retrospektivt. CT er kun anbefalt der diagnosen er uklar. Leverbiopsi vil vise mikrovaskulær steatose, men er ikke rutinemessig anbefalt pga. den høye andelen pasienter med koagulopati og blødningsfare (8).

Med tanke på pasientens store vannlatingsvolum ble det foreslått redusert utskilling av antidiuretisk hormon (SIADH) og diabetes insipidus som årsak til polyuri. Med u-osmolalitet på $88 \mathrm{mosmol} / \mathrm{kg}$ (300-900) og med s-elektrolytter og osmolalitet i normalområdet var SIADH usannsynlig diagnose (9).
Intens tørste og polyuri hos gravide i 3 . trimester skal gi mistanke om diabetes insipidus. S-osmolalitet, natrium og u-osmolalitet bør kontrolleres. Ved normal graviditet vil s-osmolalitet være under $280 \mathrm{mosmol} / \mathrm{kg}$ og s-natrium være under 140 mmol/l. Når u-osmolaliteten er lavere enn s-osmolaliteten er diabetes insipidus sannsynlig (10).

Påfølgende morgen gikk vannet spontant. Vannet var misfarget. Gynekolog ved universitetssykehus ble konsultert og man var enig om at akutt fettlever i svangerskap var sannsynlig diagnose. Man bestemte umiddelbar forløsning med akutt sectio. Det ble forløst to gutter med fødselsvekt på henholdsvis $1245 \mathrm{~g}$ og $1610 \mathrm{~g}$, begge med apgarskår 9-9-9. Blødningen ble estimert til $500 \mathrm{ml}$ og det ble ikke vurdert nødvendig med blødningsprofylakse.

Når akutt fettlever i svangerskap mistenkes, bør rask forløsning vurderes uansett om tilstanden anses som mild eller alvorlig eller om det er tidlig eller sent i svangerskapet. Anbefalt forløsningsmetode er sectio, såfremt ikke vaginal fødsel vil skje omgående (8).

Første postoperative døgn var pasienten klinisk stabil med fin diurese og med fall $i$ leverfunksjonsprøvene. Andre postoperative dag oppfattet man pasienten som tiltakende somnolent. Hun luktet av ammoniakk og følte seg svimmel og svært tørst. Hun var polyuretisk, med diurese på $4000 \mathrm{ml}$ siste døgn. Samtidig viste blodprøvene fall i ALP, ALAT/ASAT, CK og bilirubin. APTT var fortsatt forlenget. Albumin og ammoniakk var så vidt stigende. Man så en bedring i evnen til å konsentrere urin, med u-osmolalitet stigende til 226 mosmol/kg. S-Na ble ikke tatt. Det var også tendens til hypoglykemi med s-glukose 3,0 mmol/l, men blodsukkeret normaliserte seg påfølgende dag. Grunnet stabile kliniske funn og lite kapasitet på intensivavdelingen ble pasienten flyttet tilbake til barselavdelingen.

Over halvparten av pasientene med akutt fettlever i svangerskap observeres på intensivavdeling etter forløsning. Median tid der er tre dager (7), og de fleste stabiliseres etter forløsningen (6). Postpartum er det viktig med støttebehandling til leverfunksjonen er normal. Komplikasjoner forekommer, og de mest vanlige er alvorlig lever- og nyresvikt, leverencefalopati og disseminert intravaskulær koagulasjon (DIC). Andre komplikasjoner inkluderer postpartumblødning, sepsis, cerebrovaskulære hendelser og kramper. Dødsfall er sjelden, men forekommer. Multiorgansvikt er den vanligste dødsårsaken. (8).

Tredje postoperative dag ble pasienten overflyttet til medisinsk avdeling. Man så daglig klinisk bedring og hun ble utskrevet etter sju dager. Hun var da i fin form. Blodprøvekontroll etter 14 dager viste tilnærmet normale verdier. 18 dager etter forløsning kom pasienten tilbake med akutt vaginalblødning. Det ble gjort revisio i venstre uterus og man fikk ut hinnerester og koagler. Preoperativ Hb var 10,9 og trombocytter 298. Hun ble utskrevet påfølgende dag $i$ klinisk velbefinnende med $H b$ på 8,6.

\section{Diskusjon}

Akutt fettlever i svangerskap er en sjelden, men alvorlig tilstand i svangerskapet og er blant annet beskrevet $\mathrm{i}$ en tidligere kasuistikk i Tidsskriftet (11). Tilstanden er rapportert ved 5 av 100000 svangerskap, og opp mot $20 \%$ av kvinner med denne sykdommen er gravide med tvillinger (7). Til sammenlikning er bare $1,6 \%$ av fødslene $\mathrm{i}$ Norge med tvillinger (2). Etiologien er ikke klar. Ofte ses en enzymsvikt i mitokondrienes fettsyreoksidasjon hos fosteret. Det er foreslått at kvinner med flerlinger har økt risiko for tilstanden grunnet en kombinasjon av økt maternell produksjon av fettsyrer, redusert fettsyreoksidasjon og økt føtal produksjon av fettsyremetabolitter (12). Det er også sett økt forekomst av alvorlig preeklampsi med eller uten HELLP-syndrom hos mødre med barn som er rammet av denne enzymsvikten (13).

Vår pasient hadde kjent mindre liv fra det ene fosteret og beskrev en polydipsi/polyuri som hadde utviklet seg over tid. Differensialdiagnosene ved polyuri i svangerskap er mange, og presis diagnose kan være vanskelig. Tilstander som diabetes mellitus, kronisk nyresykdom, hyperkalsemi og hypokalemi kan gi polyuri i svangerskapet. Vanlige plager som hyppig vannlating og nokturi grunnet fysiologiske endringer $\mathrm{i}$ svangerskapet må utelukkes (7).

Diabetes insipidus forekommer sjelden og kompliserer ett av 30000 svangerskap (14). Tørste og sirkulerende vasopressin (antidiuretisk hormon, $\mathrm{ADH}$ ) opprettholder vannbalansen og osmoreguleringen. Hos gravide ses en markant økning i metabolsk utskifting av vasopressin. Vasopressinase produseres av placenta og bryter ned vasopressin. I et normalt svangerskap vil vasopressinproduksjonen øke for å tilpasse seg den økte nedbrytingen. I sjeldne tilfeller vil nedbrytingen overgå produksjonen og eliminere all sirkulerende vasopressin. Resultatet er manglende evne til å konsentrere urin og dermed gi polyuri, tørste og dehydrering (10).

I litteraturen beskrives tre former for diabetes insipidus $\mathrm{i}$ graviditet (14) som kan klassifiseres avhengig av responsen på vasopressin og 1-deamino-8-D-arginin-vasopres$\sin (\mathrm{dDAVP})$, en syntetisk form for vasopressin. Man skiller mellom vasopressinresistent 
og dDAVP-sensitiv diabetes insipidus (diabetes insipidus i svangerskap), vasopressinog dDAVP-resistent diabetes insipidus (nefrogen) og vasopressin- og dDAVP-sensitiv diabetes insipidus (sentral). Forbigående diabetes insipidus under graviditet (transient DI of pregnancy) beskrives som en tilstand isolert til svangerskapet. Typisk presenterer den seg i 3. trimester og må vurderes som en differensialdiagnose hos kvinner med uttalt polyuri og polydipsi mot slutten av svangerskapet. Disse kvinnene har signifikant forhøyet vaspopressinaseverdier, rapportert opp mot 300 ganger det som er sett hos friske gravide. Vasopressinaseproduksjonen er proporsjonal med placentamassen. Ergo vil man hos kvinner med tvillingsvangerskap få høyere vasopressinaseverdier, nettopp fordi placentamassen er større. En annen faktor som kan spille en viktig rolle er nedsatt leverfunksjon som leder til nedsatt evne til å bryte ned vasopressinase (10). Én av ti med akutt fettlever i svangerskap angir polyuri/ polydipsi som første symptom (7). Hos vår pasient ble økende tørste og polyuri bemerket allerede fra 2 . trimester, med markant forverring fra begynnelsen av 3. trimester. På grunn av akutt fettlever i svangerskap og akutt forløsning var det ikke aktuelt å utrede pasienten ytterligere for subtype av diabetes insipidus. Dette kan gjøres med en tørstetest, men er ikke anbefalt i svangerskapet pga risiko for dehydrering (15). Pasientens symptomer forsvant få dager etter forløsning.

\section{Konklusjon}

Diabetes insipidus og akutt fettlever i svangerskap er to sjeldne, men alvorlige tilstander. Det kliniske bildet passer med at vår pasient hadde en graviditetsbetinget diabetes insipidus som ble forverret av redusert leverfunksjon da akutt fettlever i svangerskap oppsto.

Pasienten har samtykket til at artikkelen blir publisert.

\section{Alexander Nagel Tandberg (f. 1984)}

er lege i spesialisering i ortopedisk kirurgi. Forfatter har fylt ut ICMJE-skjemaet og oppgir ingen interessekonflikter.

\section{Litteratur}

1. Raga F, Bauset C, Remohi J et al. Reproductive impact of congenital Müllerian anomalies. Hum Reprod 1997: 12: 2277-81.

2. Norsk gynekologisk forening. Veileder i fødselshjelp 2014. Tvillinger. https://legeforeningen.no/ Fagmed/Norsk-gynekologisk-forening/Veiledere/ Veileder-i-fodselshjelp-2014/Tvillinger/ (28.7.2015)

3. Lutfi S, Allen VM, Fahey J et al. Twin-twin transfu sion syndrome: a population-based study. Obstet Gynecol 2004; 104: 1289-97.

4. Thadhani RI, Maynard SE. Renal and urinary tract physiology in normal pregnancy. www.uptodate. com/contents/renal-and-urinary-tractphysiology-in-normal-pregnancy (28.7.2015).

5. Riely CA. Liver disease in the pregnant patient. Am J Gastroenterol 1999; 94: 1728-32.

6. Mackillop L, Williamson C. Liver disease in pregnancy. Postgrad Med J 2010; 86: 160-4
7. Knight M, Nelson-Piercy C, Kurinczuk JJ et al. A prospective national study of acute fatty liver of pregnancy in the UK. Gut 2008; 57: 951-6.

8. Wei Q, Zhang L, Liu X. Clinical diagnosis and treatment of acute fatty liver of pregnancy: a literature review and 11 new cases. J Obstet Gynaecol Res 2010; 36: 751-6.

9. Sterns RH. Pathophysiology and etiology of the syndrome of inappropriate antidiuretic hormone secretion (SIADH). www.uptodate.com/contents/ pathophysiology-and-etiology-of-the-syndromeof-inappropriate-antidiuretic-hormone-secretionsiadh (28.7.2015)

10. Brewster UC, Hayslett JP. Diabetes insipidus in the third trimester of pregnancy. Obstet Gynecol 2005: 105 (suppl): 1173-6.

11. Lorentzen B, Roland MC, Henriksen T. En 33 år gammel gravid kvinne med kvalme, kløe og slapp het. Tidsskr Nor Lægeforen 2007; 127: 2096-7.

12. Davidson KM, Simpson LL, Knox TA et al. Acute fatty liver of pregnancy in triplet gestation. Obstet Gynecol 1998; 91: 806-8.

13. Cunningham FG, Leveno KJ, Bloom SL et al. Williams Obstetrics. 23. utg. Columbus, OH: McGrawHill, 2009: 1065-6.

14. Ananthakrishnan S. Diabetes insipidus in pregnancy: etiology, evaluation, and management. Endocr Pract 2009; 15: 377-82.

15. Kalelioglu I, Kubat Uzum A, Yildirim A et al. Transient gestational diabetes insipidus diagnosed in successive pregnancies: review of pathophysiology, diagnosis, treatment, and management of delivery. Pituitary 2007; 10: 87-93

Mottatt 18.8. 2014, første revisjon innsendt 21.5. 2015, godkjent 28.6. 2015. Redaktør: Sigurd Høye. 